\begin{tabular}{l|l} 
& $\begin{array}{l}\text { Eastern } \\
\text { European } \\
\text { Countryside }\end{array}$ \\
\hline DOI: $10.2478 /$ eec-2014-0003 & 2014
\end{tabular}

Tésits Róbert, Alpek B. Levente

\title{
Appearance of European employment policy in the rural areas of Hungarian-Croatian border region
}

\begin{abstract}
The study provides an insight into Interreg and IPA programs achieved so far, having significant impact on the labour market of rural areas. Another objective is the evaluation of the effects of labour market programs, with the help of the interviews with experts coordinating these programs. However, the CroatianHungarian cooperation was perfect, went smoothly, which is also due to the similar labour market problems of the cooperative areas. They fight with similar methods, even in the project reports, evaluations, and there are also similar results found. It has become clear that financial resource-intensive elements cooperation programs operated until they were financed. In these cases, the closing of them prevented sustainability. The non financing-intensive programs, especially if there is local demand that is not based on a faulty premise, and no fundamental changes have taken place, prove to be sustainable. The maintenance and expansion collaborations are important tasks after Croatia's accession to the EU. Croatia, by taking its own path, but with the use of the Hungarian experience, can stabilize the labour market situation in the most underdeveloped areas.
\end{abstract}

Keywords: rural employment, EU, cross-border, Croatia, Hungary 


\section{Introduction}

Croatia's accession treaty was signed in Brussels in December 2011. This took place after the Council had voted for EU admission of Croatia three days earlier. Therefore, it is more and more likely that the country - in July 2013 - will become the 28th member of the European Union, upon ratification of all current member states. By signing, however, the tasks facing the Croats have not been completed yet; there are still some issues for improvement. Nevertheless, in connection with the results obtained, the co-operation of the Croats seems to be satisfactory for everyone.

In Europe, the cooperation between neighbouring border regions has a long tradition. Impulses after World War II, the initiatives of the Association of European Border Regions, the realization of the European internal market, the EU's regional policy, as well as, the democratic progress in Central and Eastern Europe have resulted in more permeable national borders (Perkmann 2003; Dokic et al. 2006)

Following the implementation of INTERREG programs - the overall aim of which was that national borders do not pose a barrier to the balanced development and integration of the European regions - the Hungary-Croatia IPA Cross-border Cooperation Programme has been implemented during the 2007-2013 period. The program was approved by the Commission in March 2008; € 35542216 was available for the first five years of EU funding. The program offers a wide range of opportunities for potential beneficiaries in the framework of two priorities (sustainable environment and tourism, and the co-operative economy and intercommunity human resources development). In order to ensure the immediate cross-border effect, partners should be involved from both sides of the border area of Hungary and Croatia. The projects should be designed and implemented according to the so called joint cooperation criteria: joint project development, joint human resources, joint funding and joint project implementation. The results of the projects should have an impact on both sides of the border (Jessop 1995; Sodupe 1999).

The present study aims at providing an insight into Interreg and IPA programs achieved so far, that have a significant impact on labour market and call attention to those Hungarian border region EU programs, with the experience of which, the border area of Croatia can also be developed. Another objective is the evaluation of the effects of labour market 
programs with the help of the interviews with experts coordinating these programs.

\section{Results}

Social and economic characteristics of the labour market in the affected area

The area along the river Drava is considered as a "rearguard" since there has not been job creation in the last few years that has a significant effect on employment. Agriculture plays a continually diminishing role in employment because of the discontinuance of agricultural cooperative farms. In consequence of low incomes, the local market provides limited opportunities in relation to the enlargement of local employment. The facts that the rate of the Gypsy population is above average, and nearly two-thirds of unqualified people take part in the registration of employment, attach importance to the problem. Although the large-scale job reductions took place in the 1990s; there have not been improvements and investments that could induce significant employment.

Agriculture plays a minor role in employment; however, this sector has played a decisive role in the region for long decades. It is proved that the spreading of automation / motorization in production is increasingly reducing human labour in the sector. Manufacturing industry and constructing industry are represented by some private enterprises / small businesses. Due to the rearrangement of the market conditions, the profit interests of service providers came to the fore; therefore, in those small towns, where the turnover did not provide the profitable operation, the service became partial, the opening hours of shops were reduced / cut down. Multinational commercial firms have not got a foothold on the settlements on the periphery. And there is little chance for doing so in the near future; the closeness of cities, in most of the cases, does not serve as a motivating factor. Commercial firms require a slight demand for labour force, they make up for the loss of the number of the staff caused by fluctuation. The strengthening of rural tourism is impeded by the shortage of programmes, the lack of resources of local councils / governments. The majority of these settlements cannot develop their environment and reach a level which can be attractive and desirable for the guests. 
The job hunters concerned are in serious disadvantage in the field of information, connections / relationships and the ability to enforce their interests that are required to make a successful impression. To generate direct demand for the primarily low-skilled social class is seriously difficult without a radical intervention in the economic process. However, the majority of the labour market programmes ignore this social class/stratum, since the attendance requires pre-training or at least primary school education in every case.

It is also true that at the end of the last decade not only the disadvantaged but also the ones with higher education did not find work. Therefore, in this respect, nearly all of the job hunters are underprivileged in this region, as people who continue their education are also willing to work. The already operating companies are struggling to stay alive / keep their heads above the water and fighting for job retention; because of the lack of development opportunities entrepreneurs / private enterprises are on the safe side.

The regions on both sides of the examined border section are exactly those regions where unemployment, that exceeds many times the national average, spatially coincides with the lack of the ability of economic renewal. On the basis of the above mentioned facts, it can be stated that the majority of the population in the region - from the point of view of employment and self-care opportunities - is unambiguously the loser of the decades after the transition.

The primary sector employs the majority of local employees, but, out of the agricultural farms, only a few remained which actually play a minor role. The factories (functioning as the local premises of cities) were closed down and the mainly undertrained rural labour force was dismissed on a large scale, in this way, emerging difficulties for the incapable small villages. The basic economic and human factors of the spreading of enterprises could not and cannot be found here. The most significant employers are in the private sector employing a few hundred people. The majority of the businesses are family owned micro-enterprises mainly in the service sector; usually there are no opportunities for modernization and development. This serves as an example of the situation that job creation projects offered by the labour market have not been supported by the economic organizations for ages. Foreign capital shows little interest in the region. In the meantime, the underdevelopment of the economy does not facilitate the widespread 
propagation of the service sector, in that way, not even taking the advantage of self-care.

The majority of job hunters without qualification and independent decision-making abilities are characterized by intense lack of self-initiative and vulnerability. They cannot take care of themselves and their families and the decisive factors here are age, qualification, the ability to raise credit and the entrepreneurial skills. The absence of investors is strengthened by the numerous not only unqualified but also unmotivated job hunters, whose work socialization is an extremely difficult issue /case. The situation is exacerbated by the fact that the skilled labour force is struggling with deficiencies concerning training and inexperience. On top of that, they do not have the profession, which coincides with the lack of appropriate ones. Besides, these enterprises are not installed in these regions.

From the point of view of the ability of renewal in a certain sense, the situation is similar in the small regions on both sides of the border. The total lack of capital and own financial resources for development result in the lack of viable operators of economic life. A large number of private enterprises cease; at the same time, atomization inhibits collaboration and changes. The underdeveloped cooperation skills result in a very weak network of contacts and eventuate in the lack of cooperation and passing on of expertise. Small enterprises keep closing down, while their isolation is hindering changes and cooperation, and the lack of cooperation skills result in a very weak inter-corporation network and a lack of experience transfer.

What is more, the underdeveloped limited internal market, the lack of solvent demand, the underdeveloped infrastructure and; last but not least, the low educational level (nearly total lack of high education qualifications, on secondary level mainly skilled labourers) have not created the conditions for self-care yet. The already existing enterprises are not able to increase the number of their employees; due to the above mentioned facts, as well as, the underdeveloped infrastructure and the lack of industrial parks, only a few new and viable initiatives have come into existence.

The region along the river Drava has similar depressions and abilities from several viewpoints; consequently, it has similar opportunities and threats. There is no doubt; however, that the two side of the river differ from certain viewpoints. One striking difference is the historical background 
of the Croatian wars, which can be felt in the region even today. One of its particular manifestation is - besides the fact that the consequences in the urban and inter-settlement infrastructure can be clearly seen - the degradation of the traditional economic structure and; occasionally, such scale of degradation which dramatically makes the fresh start difficult (for instance this phenomenon can be observed in the region in the timber industrynow becoming almost irrelevant). It is not a negligible fact, that the areas along the borders have markedly different size. On the one hand, in Hungary, the region is small, on the other hand the 'županija's of the Croatian side are similar to the Hungarian counties in terms of size. Consequently, both the size of the centres and the volume of the problem differ from each other. The centres in Croatia have a significant volume of employment, while in Hungary, the cities (for instance Pécs, Nagykanizs) outside the small region are determinant. The peripheral nature of the given region also has a different meaning in terms of a županija and a small region. The small regions of Csurgó, Barcs, Sellye and Siklós are part of the real and marked periphery in Hungary; it is one of the most disadvantaged regions, which is situated in a great distance from the capital city; consequently, it does not have an effect on the employment.

By contrast, the Croatian territory is partly considered peripheral, or a semi-peripheral (especially Koprivničko-Križevačka Županija). In this case, the question of the proximity of the capital has an effect on the problematic issue of employment characteristics of the region. Differences also emerge in the case of investments. Due to the crisis, the volume of investments has decreased noticeably in the Croatian areas, which had a clear impact on the lives of unemployed people. This could also be observed in Hungary; however, with regard to the fact that the examined region had not attracted investments earlier, instead of the fall of the volume, it was rather the downsizing of the employers outside the region which affected the area.

A significant difference is that Croatia as a prospective EU member state receives somewhat different support than the Hungarian region, which also modifies and delimitates in some issues the scope of the regional cooperation. As a result of the size of the Croatian area, there are no homogenous depressions as on the Hungarian side of the border. For this reason, there is; for instance, a higher proportion of qualified labour force and this provides better opportunities for settling down of more advanced 


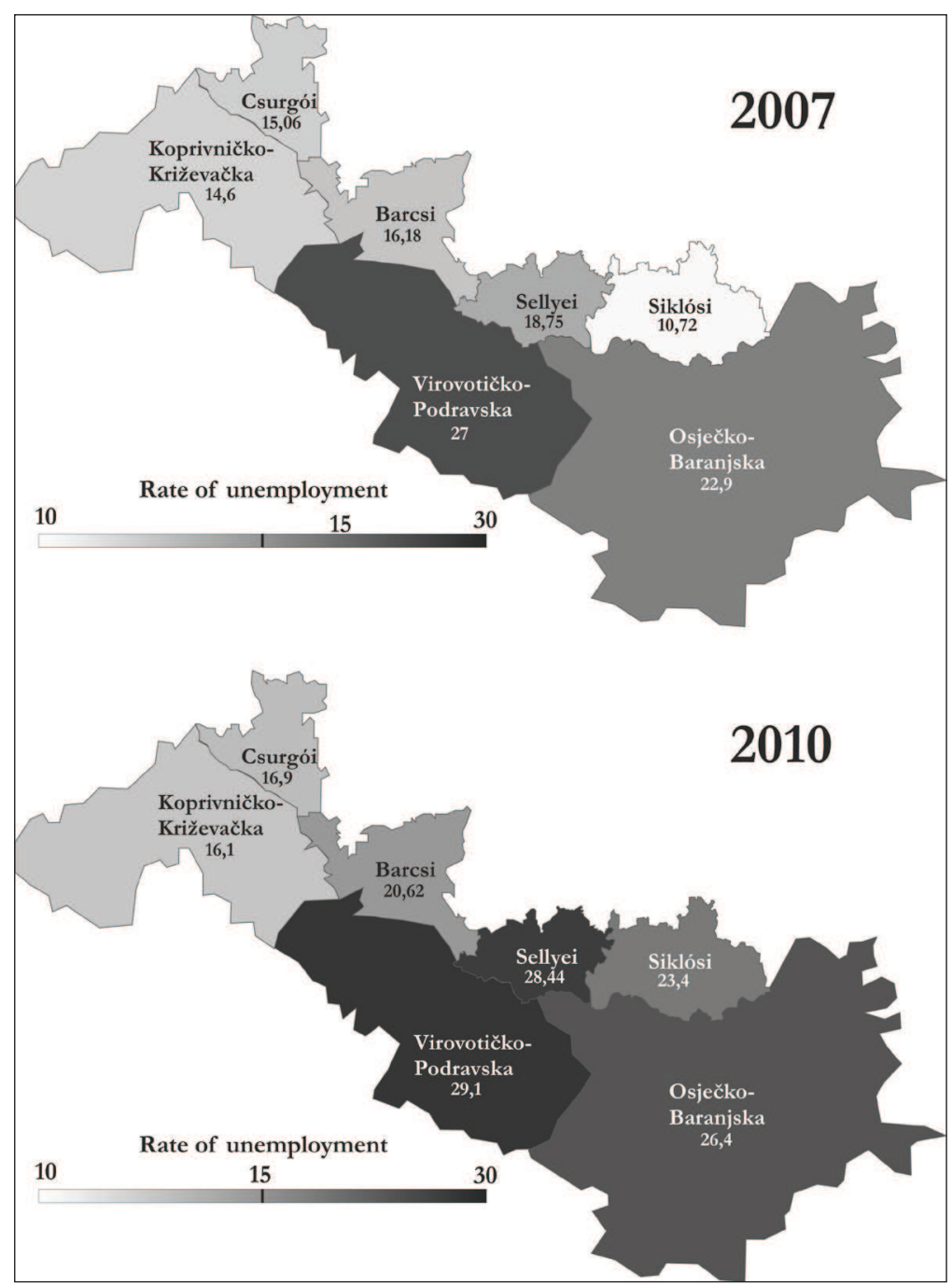

Figure 1. Regional distribution of the unemployment at the beginning of co-operation (2007) and three years later

Source: NFSZ

industries. In a macroeconomic point of view, the $5 \mathrm{c}$ transit corridor of the European Union lies in the given area of Croatia, which has a strategic importance and an economic potential, while in terms of transport, the 
Hungarian side is considered as a periphery. With regard to the educational system, it should be highlighted that on the Croatian side - it is also due to the size - the structure of training is more differentiated, a university is also located in Osijek. In addition to the fact that the problematic issues and the opportunities of the area show a significant homogeneity, the existence of internal differences must be borne in mind, while targeted and adequate efficient development programmes are conceivable if one takes into account all the above mentioned factors.

\section{Interreg and IPA programs realized between 2005 and 2012}

The main purpose of the Interreg III. (A) was to develop cross-border economic and social centres through joint strategies of sustainable regional development. The areas suitable for cross-border co-operation in this case were the NUTS III level units located along the Union's internal and external borders. At the same time, the Instrument for Pre-Accession Assistance (IPA) offers assistance to countries engaged in the accession process to the European Union (EU) for the period 2007-2013. The aim of the IPA is; therefore, to enhance the efficiency and coherence of aid by means of a single framework in order to strengthen institutional capacity, cross-border cooperation, economic and social development and rural development. Pre-accession assistance supports the stabilisation and association process of candidate countries and potential candidate countries while respecting their specific features and the processes in which they are engaged. Cross border herb collecting-growing-processing sales network
in order to improve the economy of the border region

The project was implemented as part of the Slovenian-Hungarian-Croatian Neighbourhood Programme with the financing of the European Union and the Republic of Hungary. The project was formulated in order to develop the economic region along the border. According to the previous research, the best opportunities of alternative income generation and job creation in the region are the agricultural integration programmes. Therefore, the aim was to build a self-sustaining herb collector, producer 
and purchaser cluster, which provides job opportunities and livelihood for the rural people living in the disadvantaged economic regions. It was also a purpose to develop a model which promotes agricultural integration and economic development which would be implemented in the future into other areas of economy. Due to the similar problems and potentials of the Croatian side of the border region, the participation in the project and its results provided useful experience to the implementation of a similar Croatian program, to the complete or partial adaptation of the model. The Herbal Network Project was achieved by Hungarian-Croatian cooperation. The professional partner of the project was the Osijek-Baranya County Employment Centre on the Croatian side, which aim was to achieve a similar project on the basis of the experience of the project carried out in Hungary. The long-term cooperation agreement between the Osijek and Baranya County Employment Centre was signed in 2004. Following the Herbal Network Project, the two Employment Centres submitted another collective application.

The project, by bringing of an agricultural cluster along the border into existence, created a large number of jobs (for approximately 200 people) in the region. The Croatian side of the border is facing similar problems. Since their natural endowments are similar, the project can be an example for the Croatian side. The Croatian Employment Centre on the other side of the border can make good use of the experience acquired in this project. Currently, the limited production and collection of herbs can be found on both sides of the border, and there is a limited number of businesses specializing in processing and selling. In the future, an integrated Croatian-Hungarian supplying, purchasing and processing network can develop, which could occur together on the export market. With the help of the collective flow of structured information, the process of collection can be tailored to the demand, and the loss due to seasonality can be minimized. The range of species grown in the other country (e.g. Wild garlic, Acorus calamus) represents a wider range of options for the buyers to choose from. Henceforth, the exchange of expertise can be delivered on different levels and fields of activity of the network: the co-operation of the institutions of employment centres, the application management; because the Croatian organizations concerned have never implemented such a complex application project yet; and in the field of the different sales and market knowledge of the entrepreneurs in the two countries. 
The Western European market requires the certification of the harvested/ collected plants and products (e.g. chemical free, drug content), especially in the case of organic products. Within the framework of the project, the equipment, which was put into operation at the University of Pécs (PTE), is supplemented by the already operating equipment in the region and this provides the full range of testing possibilities. The instrument is easily accessible and available for the growers of the Croatian side, so with the help of the classification, the producers and processors of both countries can achieve a higher price on the common export markets.

\section{Training for the good-quality (Pannonian) rural tourism}

The overall aim of the project was to develop the professional knowledge of workforce in the region along the border (hereinafter referred to as the "Pannonian region") in the catering industry/ establishments of the country. The aim of the project for service providers was the development and management of a cross-border specific training program guided by the facilities of the Pannonian region. The project resulted in a newly developed joint Croatian-Hungarian curriculum, which follows the recommendations of the "European Curriculum for Training in Rural Tourism" and consists of 10 modules. The indirect focus group of the project was the owners of the rural catering establishments (rural tourism service providers) and the tourists. The direct focus groups were the rural tourism providers participating in their courses. With the help of the curriculum, the target group can improve the quality of the service and it makes easier to start new rural catering establishments.

\section{„Cooperation without frontiers" Hungarian-Croatian Academy of Professional Employment (2010-2011)}

The South-Transdanubian Regional Employment Centre submitted their application in three different topics and they have won support, taking part as leading beneficiaries in two out of the three (Cooperation without frontiers - Hungarian -Croatian Academy of Professional Employment, as well as the "Learning and working" career counselling, career correction project), and also as a consortium partner (in the "Work and health" professions-health care project, with research, development and innovation). 
The support of applications was made possible through nearly one decadelong Croatian- Hungarian industrial relations. The first formal co-operation was established between the Baranya County and Osijek Employment Centre in 2001, which was followed by the agreement between the Somogy County and Virovitica Employment organizations two years later. The organization was raised to the level of regional cooperation immediately after the transformation of the region in 2007.

The Baranya - Osijek-Baranya, the Somogy - Veröce and Zala Muraköz - Varasd relations came into being along with different problems and different motivations in the past 10 years. On the one hand, the BaranyaSomogy relations indicated support of specific cross-border co-operations, on the other hand, they were carried out in several EU-funded projects. With the support of the Interreg program, two successful projects were implemented (see above), one in the framework of the Herbal Network, the other was the Pannonian Tourism; therefore, experience was gained from the joint program. The purpose of the Pannonian Tourism (completed in February 2008) was to develop and implement a training program, which suits the natural endowments of the Pannonian region in order to increase the quality of the rural tourism service. Apart from the SouthTransdanubian Regional Employment Centre, the West-Transdanubian Regional Employment Centre has experience in several cases in the field of cross-border cooperation. The Zala - Medimurje - Varazdin relation endeavoured to explore and solve the common employment problems together. In the spirit of exploring the general problem, there was the First Hungarian-Croatian Employment Conference held in Nagykanizsa in 2004; the second such conference was in Zalakaros in 2006, where the participants exchanged ideas about a specific theme, the opportunities and practices connected to employment. The second conference has left the question of institutional cooperation open; the Academy of Experts was appointed as competent in finding the solution.

The level of cooperation makes it possible that there is significant potential in business and labour market cooperation which has not been exploited yet. What is more, all these factors and the collaborations are adhoc, and there are no institutionalized relations neither among the public organizations, the employers nor the social partners. The employment situation is expected to change along the border; the project gave the opportunity of preparing for this situation. The practical cooperation 
should be started with the cooperation of experts; for this purpose the Academy of Experts was established.

The general aim of the project was supporting the Hungarian-Croatian integrated labour market along the country border. With the establishment of the Academy of Experts, the institutional cooperation can be created in the short run. There will be an opportunity of comparing the usage of the system of ways in employment policy in the long run, and as far as possible, of its coordination, joint project planning and project generating with an employment policy content. As a result of these, the economic performance will be given a new impetus by transferring organizational knowledge and learning from one another.

The Academy of Experts examined the possible areas of co-operation in workshops; they carried out their work in eight workshops and 3 Employment Policy Conferences. The experts summarized and recorded the results of the workshops and the conference in the form of studies. The project created the Virtual Academy, where the experts had the opportunity not only to publish their studies but also to work online. The resulting joint information and communications technology basis was also the aim of the project.

The employment policy experts of the labour unions identified the officers of the employers' organizations, the representatives of the social partners and the managers of the civil and non-profit organizations engaged in labour market services as a direct target group. The above mentioned got to know the methods and good practices to be used in certain areas. They will be able to reach dissemination and they will have multiplier effects in the region. The indirect target group is made up of labour unions, the employees of civil and non-profit organizations dealing with labour market services, registered job hunters in the border regions, adult education institutions and non-profit organizations along the border, and the employers who have to face with the problematic issue of skills shortages.

The operations of the project were realized on a twofold cooperation level in the same proportion on the Hungarian and the Croatian side of the border, on the axis of Pecs-Osijek and Zalaegerszeg-Csáktornya. The effects of the successful implementation of the program; in addition to the project partners, were expected to be as follows: communication and brainstorming among the civil and non-profit organizations dealing with 
employment policy, the local governments, chambers, social partners and employers; on an expert level first, and on feasible level later on. In practice, it means analysing joint labour demand, launching collective training and retraining programs and $t$ implementing shared project planning.

The IPA „Learning and working” Hungarian-Croatian cooperation along the border (2007-2011)

The aim of the project is to develop a more effective and balanced labour market along the border, both in the regions of Hungary and Croatia, with the establishment of cooperation between educational and other institutions. The project supports the target group with programs (career programs, student exchange programs, career counselling camp for the disadvantaged youth) that help to strengthen the position of the labour market in the future. During the cross-border collaboration, the training and guidance systems and methods for exchanging the best practices, and the development of cooperation between educational institutions and networking are also directly displayed. The direct target group of the project are the students learning in the Hungarian and Croatian school system, young people facing choice of career. The various elements of the program help these target groups to choose a profession with the establishment of cooperation between schools and labour organizations, events, taking over the best practices and with handing over the specific methods used in the two countries. The target group of disadvantaged young people benefits from the project in particular.

\section{Evaluation of co-operations}

The Hungarian-Croatian labour market co-operation, even if its impact on the evolution of unemployment cannot be measured and quantified, with the help of career counselling, training, or concrete work constitutes an important step towards the extension of income-producing activity.

Regarding the herb-collection, processing, production, sales network, a basic and logical assumption was that the system will work if there are people who inform collectors about the needs. Because of the need for market information, the integrator network was organized, which meant the wholesale level, and which entered between the processing plant and 
the producer. The program functioned as a mirror program, while in Hungary the target area was Ormánság, in Croatia, it was implemented separately, but similarly.

On the Hungarian side, the Baksa herbal plant of Schmidt \& Co. Healing Herbs Commercial Ltd has been dealing with medicinal and aromatic plants cultivation, collection, purchase, primary processing and trade since 1997 as a family business. The selection of the area, beyond the aspects of labour market, has several advantages. The hundreds of medicinal herbs and spices growing wild come from pollution-free good growing areas. There is a huge demand for the labour-intensive collection activities, since there are no other job opportunities. The processing is added to research and development activity of the University of Pécs using domestic folk medicine experience and the latest literature resources. The possibility of further development is given in the region with the installation of driers. If significant income generation is not available, saving and improvement in life quality can be reached. Co-operation in this part of the program embodied in the transfer of experience.

During implementation, many differences were observed on both sides of the border. The differences can be traced back to historical and cultural reasons, which fundamentally influenced its success. In Croatia, during the socialist transformation of agriculture, co-operative conversions coupled with forced industrialization was not that strong, so the conditions for the development of family farms were also given. However, because of the greater appreciation of agriculture and a more flexible regulatory background, the program was more successful on the Croatian side. The intense self-organization is aimed even to create clusters, the aim of which is the installation of processing, drying and pressing machines. The regulation relating to the primary producers and changes coming from the regional reorganization of the Hungarian labour market network hindered the realization of the plans for the professional and advisory coordination of the integrator network. The success of the Hungarian program can also be questioned in terms of the original objectives. These goals aimed at providing a long-term, although relatively modest, income-producing activity for the masses of unemployed in Ormánság. Today, some deal with herb-production. For a more successful program, certainly a long-term, time slip-free project would have been needed, so the training would not be 
in winter. The income-producing ability of the activity is strongly influenced by the fact that the plants were bought at the same price a decade ago.

At the same time, the programs aiming at technical cooperation, organizing career events, and joint curriculum development are said to be fully successful. Indirect labour market effects of these programs cannot be measured, but the 15,000 registered participants, visitors of the events speak for themselves. The Hungarian idea in Pannon Tourism program before consultation aimed at establishing a complex tourism product package broadening the host capacity and enhancing the tourist attraction of the Drava region. However, because many small family businesses deal with catering on the Croatian side, and they connect the backyard production to accommodation services, the common objective became the curriculum development of rural catering. The useful curriculum including illustrations and lectures available on internet can be used as a supplement to Hungarian NTR-training (on the official list of National Training Registry).

\section{Conclusions}

In general, while the common programs of Interreg focused specifically on employment, on concrete labour market interventions, the IPA programs were more about the conceptualization and sharing experiences. It has become clear that financial resource-intensive elements of cooperation programs operated until they were financed. In these cases, the closing of them prevented sustainability. The non financing-intensive programs, especially if there is local demand - that is not based on a faulty premise, and no fundamental changes have taken place, prove to be sustainable. In addition, the implementation of the cross-border programs was hindered by legal and regulatory difficulties, attitudinal problems, lack of tradition related to specific activities and the time delay of projects as well. A further complicating factor in sustainability, because of the conflicting interests, is the conversion of business or for-profit relations into partnership. This; obviously, should not be assessed as a failure, but rather an attempt, which laid the foundations for future cooperation, and promoted the involvement of civil society.

However, the Croatian-Hungarian cooperation in each case was perfect, went smoothly, which is also due to the similar labour market problems of the cooperative areas. They fight with similar methods, and even in the 
project reports and evaluations, similar results were found.. The Croatian partners in each case have testified flexibility; their creative attitude is due to the smaller number of administrative and legal hobbles, thus a more flexible labour market organizational background. The maintenance and expansion collaborations are important tasks after Croatia's accession to the EU. Croatia, by taking its own path, but with the use of the Hungarian experience, can stabilize the labour market situation in the most underdeveloped areas.

In the long run, there is a great potential in tourism programs that can help tourists arriving to the region to stay there for more than two days. Although the analyzed tourism program has micro-level results, which are limited to the villages of the immediate surroundings of the Drava River, the expansion of this circle would have more significant labour market effects. The expansion of the Academy of Experts to a pact would give the opportunity for the economic actors to seek the possibilities for cooperation and development. Such initiatives - although in a very different labour market environment - work well in the Austrian-Hungarian border area. In the involvement of investors, however, cooperation and not competition is the acceptable attitude; since investors could arrive to any side of the border, the positive effect would be visible on the other side as well.

Mobility, because of the equally unfavourable labour market situation characteristic of both sides of the border, is not worth talking about. In July 2013, border will be abolished, but this will not mean more jobs. Without jobs, Croatian workers will certainly not stop at Pécs, the center of the South-Transdanubian region. If one side of the region could attract investors, together with the suppliers, a cluster could be built on both sides.

\section{References}

Jessop, B., 1995. 'Regional Economic Blocs, Cross-Border Cooperation, and Local Economic Strategies in Post-Socialism: Politics, Policies and Prospects', American Behavioral Scientist. Vol. 38 (5): 674-715.

Perkmann, M., 2003. 'Cross-Border Regions in Europe: Significance and Drivers of Regional Cross-Border Co-Operation', European Urban and Regional Studies, Vol. 10: 153-171. 
Dokic, I. et al., 2006. Croatian experiences in establishing new modes of governance through the EU Neighbourhood Programme Slovenia-Hungary-Croatia. Mexico City: World Planning Schools Congress.

Sodupe, K., 1999. 'The European Union and Interregional Cooperation', Regional and Federal Studies. Vol. 9 (1).

Rechnitzer J., 1999. Határ menti együttmüködések Európában és Magyarországon [Cross-border co-operations in Europe and Hungary]. In: Nárai, M. and Rechnitzer, J. (ed.) Elválaszt és összeköt - a határ [Separates and connects the border]. Pécs-Győr: MTA RKK.

Rechnitzer J., 2001. A határ menti regionális együttmüködés sajátosságai és a fejlesztés lehetséges irányai [Features and possible directions of development in crossborder regional cooperation]. Nyár: Pro Minoritate. 